\title{
Theoretical and empirical aspects to food in North and South America
}

L'alimentation: enjeux théoriques et empiriques dans les Amériques

La alimentación: cuestiones teóricas y empíricas en las Américas

\section{Philippe Cardon and Domingo Garcia-Garza}

Translator. Michael Hinchliffe

\section{(2) OpenEdition}

\section{Journals}

Electronic version

URL: https://journals.openedition.org/ideas/2293

DOI: 10.4000/ideas.2293

ISSN: 1950-5701

This article is a translation of:

L'alimentation : enjeux théoriques et empiriques dans les Amériques - URL : https:// journals.openedition.org/ideas/403 [fr]

Other translation(s):

La alimentación: cuestiones teóricas y empíricas en las Américas - URL : https:// journals.openedition.org/ideas/2294 [es]

A alimentação: questões teóricas e empíricas nas Américas - URL : https://journals.openedition.org/ ideas/3139 [pt]

Publisher

Institut des Amériques

\section{Electronic reference}

Philippe Cardon and Domingo Garcia-Garza, "Theoretical and empirical aspects to food in North and South America", IdeAs [Online], 3 | 2012, Online since 26 February 2018, connection on 20 October 2022. URL: http://journals.openedition.org/ideas/2293 ; DOI: https://doi.org/10.4000/ideas.2293

This text was automatically generated on 20 October 2022

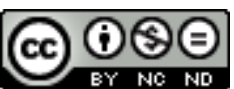

Creative Commons - Attribution-NonCommercial-NoDerivatives 4.0 International - CC BY-NC-ND 4.0 https://creativecommons.org/licenses/by-nc-nd/4.0/ 


\title{
Theoretical and empirical aspects to food in North and South America
}

\author{
L'alimentation: enjeux théoriques et empiriques dans les Amériques \\ La alimentación: cuestiones teóricas y empíricas en las Américas
}

Philippe Cardon and Domingo Garcia-Garza

Translation : Michael Hinchliffe

1 Food has so far had only a marginal role in the study of South American societies. By contrast, the study of how society eats has been taken much further in the United States and Canada, as indeed in Europe. The ambition of this third issue of IdeAs is to help fill the gap and give new impetus to a field which, though forgotten or left largely unexplored by social science, is yet powerfully present in cultural representations and daily practice on both sides of the Atlantic. A further aim of the studies gathered here is to place the sociological, anthropological and historical aspects of food throughout the American continent in a comparative perspective.

2 As a "total social fact", food provides a highly fruitful line of approach for the study of society. Historians and anthropologists were among the first to have adopted it. In Europe, Claude Lévi-Strauss (1964), Fernand Braudel (1967) and later Jean-Louis Flandrin and Massimo Montanari (1996) opened up rich avenues of research. In America, the works of historians such as Garnsey (1999), Gabaccia (1998), Bauer (2001) and anthropologists such as Douglas (1965), Goody (1982), Mintz (1996), Mintz and Dubois (2002), constitute so many references. Research on the subject of food conducted in Latin America or published in Spanish or Portuguese has been historical in perspective (Feyre, 1933; Cascudo 1983; Flores, 2003; Fernandez-Armesto, 2004; Magalhães, 2004; Bourgues et al., 2009) or anthropological (Vargas, 1993; Ortiz et al., 2004; Contreras and Gracia, 2005; Carrasco, 2007; Bertran, 2010) and, in some cases, pluridisciplinary in nature (Osegura, 2003; Long-Solis and Vargas, 2005). These latter studies look mainly at the symbolic and folk aspects of food or its function as a regional identity marker or again at food practices in minority groups (de Suremain and Katz, 2009). 
3 The various contributions to this third thematic dossier in IdeAs centered on food in American societies (in both English and Spanish speaking contexts) suggest sociological, anthropological or historical approaches to the fact of food. The first focus is on food as an identity marker, whether for different social groups or national entities, sometimes in a nationalistic perspective, in Latin-American or North American countries. Some contributors discuss the importance of social distinctions relative to food, the invention of a "tradition" in food and, indeed, the "fabrication" of an approach to food as part of a national or nationalistic discourse. Other contributions deal with the production and consumption of local foodstuffs together with the economic and social conditions implied by their presence on the local or international market. Some articles also analyze how the spread of food products from country to country affects the food practices of migrant populations, particularly those moving from south to north, a study which leads into the question of how a process of "crossbreeding" has produced various Latin-American cuisines. Hence, food, while remaining a powerful identity marker (both for class and national identity), plays a role in the "crossing" or hybridization of food practices, processes particularly noticeable in relation to population migration. A question running implicitly through all these studies is that of the propagation of food styles, modes and norms, as exemplified by the spread of new gastronomic norms among Brazilian elite classes (Carolina Pulici), by the rise of new "ethical" food norms in certain Canadian populations (Josée Johnston et al.), by the introduction of a new luxury product in a population as a whole (Natalia Milanesio), by the adoption of popular food practices by more privileged classes (Garcia-Garza), by the arrival of the creole model in Argentina, Cuba and Mexico (Jeffrey Pilcher), or that of "hybrid" food practice between the United States and South American countries (Maximino Matus) or again that of North American food practices among Mexican migrants (Frida Calderon-Bony). A parallel question is that of the social conditions in which these new food styles are appropriated by the populations involved. One of the key theoretical questions this thematic dossier raises is the extent to which the prolific French sociologies of food (Poulain, 2001, 2002, 2012; Corbeau, 2000; Poulain and Corbeau, 2002; Régnier et al., 2006; Fischler and Masson, 2007), might be transposable to societies in the Americas.

\section{Food as a factor of social differentiation}

4 Several researchers have stressed the way in which food constitutes a social marker, for example, a study of how the food budget affects living standards in Mexico (Martinez y Villezca, 2003; Torres and Trápaga, 2001), or a study of how the sale of certain foods constitutes an economic alternative to social exclusion in "developing" countries (Babb, 1987; Tinker, 1997; Chaves, 2006; Garcia-Garza, 2009). Studies such as these can be placed within the more general problem of the social differentiation established by types of consumption, a problem well aired in European and more especially in French sociology (Herpin and Verger, 2008) since the initial work done by Maurice Halbwachs on working class food consumption and pursued by his intellectual successors, particularly Pierre Bourdieu and Claude Grignon. The latter have amply demonstrated the importance of the socially diverse nature of food consumption which, notwithstanding certain dishes and regional, national or otherwise traditional gastronomies, remains deeply under the influence of structural effects induced by 
membership of a given social group (Grignon and Grignon, 1980; Régnier et al., 2006), by factors such as age and life cycle (Cardon, 2010, 2009a, 2009b; Cardon and Gojard, 2009; Gojard, 2010), or region (Poulain, 2001). Furthermore, the emergence of a new type of food offer, resulting from the development of the agro industry, supermarkets and fast food or the arrival of new products (e.g. frozen foods), has not meant the end of certain "local food cultures" (Poulain, 2002). Food, then, remains a powerful social marker on account of practices specific to certain social groups.

\section{Implications of the problem of class distinction}

Classically, the study of the social structure of consumption leads to an analysis of the mechanisms of class distinction, as in the case of Pierre Bourdieu's major work La distinction [trans: Distinction: a Social Critique of the Judgment of Taste] (1979). In this work, Bourdieu argues that social position within social space determines life style and, by extension, taste, especially socially marked taste, in food. (Bourdieu, 1976) In as much as taste has a classifying effect, that is, it underlies social classification, it is a marker of social position within the social space. In this issue of IdeAs Johnston, Szabo and Rodney, together with Garcia-Garza demonstrate that social characteristics have a considerable influence on food consumption. Johnston et al., for example, show how an ethical diet has evolved in Canada on the basis of the observation of two distinct social groups (popular versus privileged). They emphasize the key role played by cultural capital over and above social origin in consumer motivation when it comes to purchasing "green" produce or produce that helps to preserve health and the environment. In his article, Garcia-Garza highlights the ennobling process whereby popular foods become part of a redefinition of the legitimacy of the food hierarchy in Mexico.

Other papers in this issue demonstrate how new styles in food do not necessarily eclipse social difference or the symbolic relations between social classes. It turns out that new food habits mark out as clearly as ever the symbolic limits between different social groups (Bourdieu, 1979; Cole, 2008). Lamont (1992) for example, has shown that boundaries established on a three-tier categorization (socio-economic, cultural, moral) will integrate or exclude members of a given society on the basis of status, possession of resources and social advancement. She demonstrates the correlation between lifestyle and differing social status. This question is one Bourdieu (1979) raised in his study of the cultural dimension in the play of social differentiation.

Generally, the fact that social differentiations persist at both ends of the social scale independently from the propagation of new food styles brings us back to the debate about cultural omnivorousness (Peterson, 1992; Peterson and Kern, 1996; Duval, 2010; Coulangeon, 2011). Food, like any other cultural practice, is governed by the play of social differentiation in relation to the position of individuals and groups in the social space and even more so in relation to levels of education and to socio-cultural origin. Cultural practice thus corresponds to differing social class. Omnivorousness is only to be found in privileged groups, and then only when these groups display towards cultural practice, an "enlightened eclecticism", in other words, a selective cultural diversity (Donnat, 1994; Eloy and Paletta, 2008; Eloy, 2012). To put this differently, the cultural practices associated with eclecticism are present only amongst privileged social groups. Furthermore these eclectic behaviors occur only in specific instances, 
since privileged social groups prefer cultural practices consonant with their social origin. As Johnston and Bauman (2007: 198) point out, Bourdieu noted that a tendency to omnivorousness emerges in individuals with a cultural capital richer than their economic capital (specifically members of the teaching profession), resulting in an ascetic approach to consumption coupled with a propensity to "exoticism" and "populist cuisines" (Bourdieu, 1979: 207). Several of the pieces in this issue of IdeAs serve as a measure of the force and validity of the theory of cultural legitimacy Bourdieu began to elaborate towards the end of the 1970s.

\section{Appropriating new food models}

One of the key directions in this issue is thus to account for the social appropriation of new food models, on the one hand new gastronomic practices, as in Carolina Pulici's study of Brazilian elites (bankers, ambassadors, art collectors, industrialists, businessmen, persons of private income), on the other, ethical food practices in Canada as studied by Josée Johnston and her colleagues. The authors of these papers seek to understand in what way and under what social conditions new food models function, or do not function, as a basis for social differentiation. Carolina Pulici, re-engaging with a method initiated by Norbert Elias in The Civilizing Process, sets out to analyze both etiquette books recently published in Brazil and gastronomic reviews appearing in the Sao Paulo press between 2005 and 2009 in order to identify the norms which are established today as legitimate with regard to cuisine and table manners. She shows how Brazilian elites reappropriate, or fail to reappropriate, the new food norms in social representations of themselves or in their relationship to other social groups and how these new norms enable the elite to place themselves socially in relation to other groups, the popular classes in particular. Over and against popular food practices considered by the elite classes as "voracious" (this "popular voracity" being assimilated to the expression of natural sentiment), the elite prefer a food culture which eschews precisely those aspects of perception specific to the popular classes. And so what amounts to a censorship of natural sentiment functions as a rule instituting the moderation of appetite, a rule of restraint and esthetic sense that becomes the hallmark of a bourgeois food style. Thus the appropriation of the new gastronomic cuisine shores up social difference in as much as it contributes to the establishment of a social representation and an ethic based on self-control. Carolina Puici, adopting Elias's theory of self-control in European society, writes "whereas the 'populace' who expects less from the future remains bound over to sensual experience, the elite evinces selfmastery in all respects, that is to say the exercise of control not only over bodily appetite but also over living conditions, both ideal and material." Here, food practice, because it is linked to an ethic of existence specific to a group, is a means to preserve and mark out distance from other social groups, hence to establish differentiation. These new norms of gastronomy are assimilated by the Brazilian elite with a degree of ease commensurate with the way in which they function as a repertory of symbolic value which guarantees distinction and distance from other social groups on the basis of self-restraint.

However, can it be said that what provides distinction provides differentiation in the same degree? This is the question addressed by Josée Johnston et al. in relation to the spread of so-called "ethical" food in Canadian society, a food model vigorously promoted by public authorities who see in it a new potential market and the source of a 
kind of added value for public health. Basing their study on a qualitative survey (40 families), Johnston and her colleagues examine whether ethical food, a practice supposedly confined to prosperous classes, may also be adopted by other social groups, in particular popular classes. Their aim, in other words, is to find out how the discourse on ethical food is perceived and practiced by consumers who do not share the same degree of privilege. Their study falls into two phases. Firstly, the question is whether or not there are class differences in the symbolic apprehension of ethical food, whether the idea makes sense for individuals belonging to different social categories. This entails looking at the ways in which social discourse models food practices, a study for which they employ the concept of "cultural repertory" (Lamont, 1992; Tilly, 1993; Swidler, 1982, 2001) borrowed from cultural sociology (they in fact develop a concept of "ethical food repertory"). This allows them to describe the "creative [manner] in which social actors use selected elements from this discourse" on ethical food. Secondly, following Durkhein and Mauss (1903), Becker (1963) and Douglas (1966), they call into service the concept of "symbolic frontiers", whereby individuals set up limits to enable self-distinction and to signify membership of a group. Tested against individual discourses, this double conceptual approach allows them to demonstrate that economic and cultural privilege enable easier access to the dominant food ethic, whereas persons from socio-demographically and ethnically popular or marginalized environments tend to be excluded from it. Inversely, middle-class whites constitute the group most widely concerned by the ethical food repertory. Nevertheless, the study of everyday food practices also reveals the possibility of disparities between the acknowledgment of a legitimate discourse on food and actual practice. On the one hand, though economic and cultural privilege provide access to the dominant repertory, they do not "guarantee a high degree of implication" in practice. For a good many persons from privileged environments, independently of any implication in ethical food, what counts as a marker, and, by extension, as a culturally distinguishing factor is adherence to an overall "healthy" approach to food. On the other hand, the fact that marginalized groups are less engaged in ethical food does not mean "that they feel less concerned by the moral dilemmas involved in the choice of food". For Johnston and her colleagues, this result is of central importance since it confirms studies refuting the contention of some moral deficiency in popular classes making them unaware of the moral aspects of food, or, if aware, largely unconcerned and unaffected by them (Johnston, Szabo and Rodney).

\section{Food as a factor of national or nationalistic identity}

10 Where some tastes in food continue to function as powerful social markers, differentiating between social classes, others acquire "national heritage" status as common property and so become emblematic: cultural markers that transcend class difference. Food then can be studied as a purveyor of identity (Pilcher, 1998; Thiesse, 1999; Bruegel and Lauriaux, 2002). Following on from European research (Poulain, 1997, 2000, 2005; Espeitx, 2008; Bessière and Tibère, 2010), certain researchers across the Atlantic have done work on the heritage process involving Latin-American cuisines, where food practices are seen as an element of cultural heritage and form a basis for national identity (Florescano, 1993; Álvarez, 2002; Cottom, 2004, 2007; Álvarez and 
Medina, 2008; Moncusí and Santamarina, 2008; Zapata, 2008), yet study in this field relating to Latin America is still embryonic (Bak-Geller and Katz, 2011).

The bi-centenary celebrations of independence in Latin-American countries provided an excellent opportunity to look at the position of food in the societies of these countries. And indeed, there were instances in which national dishes were lauded. Very few studies, however, adopt sufficient distance to examine exactly how these dishes participate in the definitions of national identity in Latin-American countries in these early years of the $21^{\text {st }}$ century. Yet it is a point of great interest to see how national identity is built up, not only in the light of the past but also, and to a greater extent, in relationship to the outside. From north to south, different food styles that are part of the definition of national identity all have a relationship of repulsion or attraction to international food. Mexico, for instance, constantly appeals to its pre-Columbian past to construct "Mexican cuisine", even though no such thing ever really existed as such prior to the $20^{\text {th }}$ century, since it arose from the coalescence of a variety of exogenous and endogenous elements and techniques (Pilcher, 1998). At the opposite end of the scale, Argentina rejects its food of the past, seeking definition only in strong outside links, an evident result of recent migrations from Europe. This translates as a form of culinary cosmopolitanism (Pilcher, 2012), at least in the region known as the Pampa (Milanesio).

\section{From downward propagation...}

12 In some cases, national food, or national heritage food, as a social construction, may become both a basis, or a tool, for nationalist propaganda and the object of such political propaganda. Food, once it is touted as a national emblem, may serve towards uniting the people of a country and so become a key element in a strong, nationalistically oriented political ideology. Natalia Milanesio, in her study of the role played by the production and consumption of beef in "Peronist" (cf. the former Argentinian president, Juan Domingo Perón) propaganda, shows exactly that process. In her review of the structural and institutional aspects of Peronist food policy in the 1950s, Milanesio uses the concept of the "semiotic virtuosity" of food, as developed by Arjun Appadurai (1988), meaning the capacity of a cultural sign to transmit multiple messages, in order to highlight the ideological use made by the State of the role of food, and particularly the symbolic implications of beef consumption in food policy. As she states in conclusion, Peronist beef policy prior to 1950 went beyond a mere increase in consumption per person, "it redefin[ed] the image of Argentina in the world economy, and validat[ed] the concept of economic self-determination and [brought] into question the role of international capitalism" at least at the level of discourse. Traditionally seen as a luxury food, meat was to be the symbol of popular classes obtaining access to a new commodity and consequently to a new place in society. Peronist policies contributed to the propagation of meat consumption to political ends; via its beef policies, Peronism placed national consumers above those of the international market, thereby promoting a powerful ideology of economic sovereignty. Aside from the political, electoral stakes involved (certain associated with populism) the erection of beef as a national emblem and helped to redefine traditional male and female roles: "traditionally the province of women, the dishes recommended by the Peronist government were a reaffirmation of the role of women in the construction of a national culinary identity, which 
represented a shift away from the male figure of the asador." In Argentinian tradition, the involvement of men in cooking is restricted to the grilling of meat.

This example is a good illustration of how the vertical propagation towards the popular classes of a certain type of food, an incontrovertible social marker in as much as it is confined to the elite, may become the foundation of an overall nationalistic policy. The question of the propagation of taste is a central one in the sociology of food since it induces a dynamic, as opposed to a static, vision of social space and differentiation. Social groups can be seen borrowing from other groups features specific to them. And, as we have seen in the case of Peronist food policy, other groups work hard to propagate the food model of their choice. This propagation of taste and food models transcends symbolic class frontiers (Milanesio; Garcia-Garza; Pilcher; Johnston and Bauman, 2010) which clearly shows that food is far from being an innocuous or politically neutral subject. Since food is the concern of all individuals, from the moment the State is responsible for guaranteeing both the conditions of access to it and a certain degree of quality for the safeguard of public health (Stanziani, 2005), then food becomes a political issue.

\section{... to upward propagation}

This vertical propagation also occurs in the upward direction, as Domingo Garcia-Garza shows in his article on popular practice with regard to tacos (stuffed savory pancakes) in the city of Monterrey in Mexico. Tacos, originally perceived as a popular product, spread throughout social space from the 1990s onwards owing to the fact of their corresponding to the taste and consumption habits of various social milieus, the betteroff in particular. Despite this ubiquitousness, the gaps between social groups remained as before. Garcia-Garza shows that the condition of this "embourgeoisement" of a type of food and of popular practice was an up-market movement and a recontextualisation of the food within a framework that brought in into conformity with the canons of classic restoration. And the operation itself was only made possible by virtue of the fact that the revalorized image of tacos came to function as a contribution to national identity. But this contribution in its turn can be explained by the fact that the practice of tacos expresses the notions of terroir and authentic local produce, especially when ingredients which are today labeled as "gourmet" are used. Tacos with insects, grasshoppers or huitlacoche (a fungus growing on maize considered as the equivalent of caviar in Mexico), formerly considered as below notice, have today become a source of national pride and social distinction mainly for the elite classes, a shift which amounts to a redefinition of the legitimacy of popular dishes, and thus of the hierarchy of foods in Mexico.

\section{Propagation and transformation of taste from country to country}

The cases studied hitherto were concerned more or less explicitly with the question of the propagation and circulation of food styles between social groups within a national context, but this question is explicit when it comes to the cross-border circulation of food products. It has been a much discussed problem, both in Europe and the United States, especially in relation to the global propagation of food models and their 
adoption or non-adoption by national cultures. Hence the "McDonaldization-ofsociety" theory developed in the early 1990 s (Ritzer, 1993) and today much criticized, is countered by the "mass-customization-era" theory (Taylor, Smith and Lyon, 1998), which claims that the propagation of extra-national food styles requires a certain degree of conformity with local habits of consumption. In this perspective, the point of observation is the national, that is the local, dimension: the researcher seeks to examine how imported, extra-national food styles are adopted, or not adopted, within a given national territory.

\section{The influence of national context in the propagation of international models}

One of the issues here is how a national space deals with its own local and national traditions in a context of strong global propagation of transnational practices. This relationship between local and global is the subject of Jeffrey Pilcher's article on three Latin-American countries: Argentina, Cuba and Mexico. He studies the interaction between local and international practices in a historical perspective, showing the extent to which the two interlock, but this very interlocking varies in relation to national context. Criolla cooking (as developed in the new republics that arose from the dislocation of the Spanish empire) is more or less asserted as a practice, depending on the resources available, on the age of the nation's independent status, on its international relations and on the internal play of political forces. Eating a la creole is a more assertive practice in Cuba and Mexico (even though the term itself has been officially dropped) than in Argentina.

17 Pilcher's work begun some ten years ago and still more or less disregarded in France, shows how national cuisine and identity are defined in relation to the principal culinary models obtaining in the countries that functioned as models for Latin America, that is France, Spain and England. His suggestion is that what eating a la criolla in fact signifies is adapting European dishes to available ingredients and local whim. But the process occurs neither in the same manner everywhere, nor with the same ingredients, and the tendency is affected by the fact that the relations of the three countries studied with former colonial powers differ considerably. The contribution of this comparative approach is to show to what extent the mechanisms of propagation and integration of new foods, dishes or food styles, from global to local levels, are best apprehended while bearing in mind national context and the persistence of certain local specificities. Pilcher shows how three culinary traditions, far from setting themselves against globalization, bring both patriotism and cosmopolitanism to bear in the invention of new national or criolla cuisines. The cuisines of Mexico, Cuba and Argentina are, each in their own way, emblematic of the process of culinary syncretism that came into play at the end of the $19^{\text {th }}$ century. Pilcher's study of the propagation of the criollo model in culinary literature and practice in Argentina, Cuba and Mexico evinces the articulation existing between these two levels. Where, in Cuba the term criollo came to be used for local food products in the category of viandas (tuberous plants like manioc, potatoes, sweet potatoes, etc.), in Argentina, it ended up including a wide range of local products, from Hispanic specialties like empanadas or pucheros to squash soups and native maize. In Mexico, on the other hand, the term criollo(a) was never really adopted. Mexican cooking developed the same practices as the other two countries, adapted to the 
political climate of the time and local taste. Criolla cuisine has in fact always existed in Mexico, but it was never called by the name because the term criollo retained its old meaning (it designated Spaniards born in Mexico), the connotations of which were too marked and therefore unappealing to Mexicans imbued with nationalist sentiment. Hence, by eliminating the words to designate them, Mexico evacuated the Spanish origin of, and Spanish influence in, its cuisine. Mexican elite classes, mostly European in origin though they are, see themselves as heirs of the Aztecs and of their culinary traditions. Yet, even as they posit a Mexican cuisine with its pre-Columbian sources, they exclude and marginalize indigenous populations in contemporary society. Thus they have appropriated an indigenous past to constitute a national cuisine and make a place for themselves in the process of westernization. But this has meant both wrenching criolla cooking from the grasp of the indigenous peoples who invented it and erasing the traces of European contribution. It is as if any foreign origin of culinary practice had to be cast aside for a national character to evolve. Which represents one way of severing ties with a (painful) past in order to invent a present more compatible with the nationalistic ideals born in the wake of the Mexican Revolution (1910-20).

\section{Food and migration}

18 This socio-historical perspective can be combined with more ethnographically oriented approaches for the purpose of studying the mechanisms involved in the circulation of food products when international migration occurs, notably from Latin-American countries towards the United States. One of the key issues we shall be concerned with, and which runs through two studies appearing here, is that of the social conditions which cause migrants from southern American countries to the US to preserve the food habits of their country of origin or to develop different ones. It is not merely a question of discerning how extraterritorial models are appropriated in a national territory, but of examining the conditions which enable local habits to stay in place within a process of international mobility. Several directions can be envisaged.

One of them looks at precisely what comes into play with regard to identity in the circulation of food products. In both the studies presented here, food acts as a "reminder of identity" which transcends the foodstuff itself. In his article, Maximino Matus examines the strategies used by groupings of distributors and individuals in the clandestine circulation of foodstuffs to and from the US and various Latin-American countries, the raison d'être of which is to address and satisfy the "nostalgía de un migrante por el sabor, olor y textura de un alimento". He notices that whereas shops and restaurants offering Latin-American products and foods are frequently to be found in the United States, inversely, products from other countries in the world are commonplace in the home-countries of migrants. Matus proceeds to draw up he calls "paysages alimentaires hybrides" - "hybrid food topographies"; He argues that the diversity of types of migration within Latin-American countries and from these to the United States results in a hybridization of food practice among migrant populations which affects not only the migrants themselves, but also their countries of origin. The instance of the town of Oxcutzab in south-east Mexico is exemplary here. It boasts Asian, Italian, French and North-American restaurants. Matus suggests that the development of these "hybrid" food offers has to do with demand on the part of migrants tinged with a certain nostalgia for new food habits developed during migration, particularly towards the US. And this is precisely the subject Calderón-Bony 
studies, i.e. the nostalgia for food habits evinced by migrants from the town of Patamban in Mexico who have settled in the United States. Her study seeks to determine what place food has in the dynamics of identity as linked to migration. She stresses the extent to which, here again, migrants are strongly attached to certain food habits. Food products are thus exchanged between their old and new countries and vice-versa in the form of foodstuffs sent to families in the home country. One of the empirical factors observed by Calderón-Bony is the nature of the cause of the attachment observed in migrants for certain dishes linked to their origin: no other than nostalgia (Camou, 1994; Pilcher, 2012).

Another direction is linked to the development of an "offer" in food directed towards the United States from the home countries of migrants and from the market of foodstuffs originating in Southern America. Calderón-Bony provides an analysis of the "nostalgia market", as understood by Hirai (2009), in the context of Mexican emigration towards the US. The notion of "nostalgia market" refers to the process whereby "a migrant attempts to define the link between opening a commerce in Mexican products as an economic activity conducted by the migrant and creating an offer of products that possess an identifying role for Mexican culture". The commerce in question may be a small grocery store specializing in edibles such as varieties of tinned chili, maize for pozole, tortillas, and tostados, maize leaves for tamales, fresh cheese, or it may be a larger type of store, more like a supermarket. Hence migration leads to the emergence of a new food offer in the country of destination for migrants from Mexico. Matus notes the same phenomenon, but also shows that concomitant with the new offer is the development of "clandestine markets". Whereas foodstuffs can be circulated easily to meet high demand between countries in South America, the same is not the case in the direction of the US on account of the stringent health regulations applied to imported foods. Given the pressure of the demand for food products from migrants' home countries, Matus examines the ways in which economic agents (especially shopkeepers) attempt to evade what he himself calls the "políticas persecutorias" used to keep certain products out of North America. He demonstrates how a clandestine market distributing certain food products has evolved (for example, from Oaxaca to Los Angeles, via Tijuana). The growth of these unofficial markets seems partly to satisfy the food nostalgia experienced by migrants, whether or not they have settled in the US.

21 Nevertheless, the availability of stores in the new country does not mean that migrants receive no foods from their family in the home country. So, alongside the presence of official and less official markets, there exists a "private" circulation of foodstuffs taking place within family networks. Calderón-Bony demonstrates this very well, showing that first of all, where goods, such as money, move from new country to home, food moves in the opposite direction, from home to new country. And, as she goes on to say, "the circulation of foods from the home village to the US feeds a sense of proximity and strengthens links (with both family and friends), just as it helps in the 'digestion' of distance". This is indeed a central point in that it harks back to the idea of mana put forward by Marcel Mauss (1924), arguing that in an exchange, the spirit of the thing exchanged circulates as much as the thing itself. This makes it easier to see how the "here-made dish" is never quite the same as the "home-made dish". What actually circulates, more than the food, is the spirit linked to the food, the spirit of family. Here, exchange helps migrants to preserve their attachment to fellow countrymen. But can it be said that nostalgia is the mana, the spirit of the thing? Or, to put it differently, is the 
food eaten because of nostalgia for it, or is nostalgia experienced because the food is eaten?

The third direction concerns the fact that new habits from the destination territory are adopted and contribute to an identity continuum between "here" and "back there". This perspective is more or less implicitly present in Matus's study through the concept of hybrid food (which necessarily presupposes a juxtaposition of food styles as a result of multiple adoptions along the trajectory of migration). In Calderón-Bony's article, it is central to her analysis of the status of food. She demonstrates that in the case of the migrants studied, there was also an appropriation of American food culture. Hence, it is not a question of opposing the "preservation" of the habits of home to the "change" involved in the new country, but rather a question of conceiving of both dialectically and dynamically as, in fact, the basis of a new identity dynamic. Here, food functions as an identity factor in migration in as much as it contributes both to the preservation of links with family, home country, region, village and to the integration of new values from the receiving culture. Calderón-Bony is not concerned with revisiting the integration versus assimilation problem and the main interest of her study lies in her demonstration of how identity constitutes a dynamic process in which food plays a part. The emphasis she places on this dynamic dimension of the identity process through food by means of the adoption of new food styles particular to the new country implies a classic questioning of the issues surrounding the propagation of food models in society generally. A further interest of her study is that she takes into account a generational dimension in her understanding of the propagation of American food models in migrant families. In this way, she shows that the children are the vectors and propagators of new food habits and that, rather than clashing with the old habits, the new ones fill them out or remodel them.

Taken together, the studies gathered in this third issue bear witness to the profusion of approaches and questions at present to be found in social sciences studying food in the Americas. They provide proof of the heuristic value of theoretically and empirically based studies contributing to dialogue and exchange not only between disciplines but also between countries and continents. They stand as an invitation to pursue a NorthSouth dialogue with other countries and on other subjects, just as mobility, circulation and migration are at the very heart of all human societies.

\section{BIBLIOGRAPHY}

ÁLVAREZ Marcelo, «El gusto es nuestro. Modelos alimentarios y políticas de patrimonialización», Catauro: Revista Cubana de Antropología, nº 5, 2002, pp. 61-78.

ÁLVAREZ Marcelo y MEDINA Francisco Xavier (eds.), Identidades en el plato. El patrimonio cultural alimentario entre Europa y América, Barcelona, Icaria, 2008.

APPADURAI Arjun, «How to Make National Cuisine: Cookbooks in Contemporary India», Comparative Studies in Society and History, vol. 30, $\mathrm{n}^{\circ}$ 1, 1988, pp. 3-24. 
BABB Florence, «From the Field to the Cooking Pot: Economic crisis and the threat to marketers in Peru», Ethnology, vol. 26, n. 2, 1987, pp. 137-149.

BAK-GELLER Sarah y KATZ Esther, «Semana de Estudios de Cocina y Alimentación en América Latina», Guadalajara (México), Congreso Internacional "De los primeros recetarios nacionales a las cocinas patrimoniales: 200 años de nacionalismo culinario en América Latina”, 12-15 sept., 2011.

BAUER Arnold J., Good, Power, History: Latin America's Material Culture, Cambridge, Cambridge University Press, 2001.

BAUMAN Shyon y JOHNSTON Josée, «Democracy versus Distinction: A Study of Omnivorousness in Gourmet Food Writing», American Journal of Sociology, vol. 13, n 1, 2007, pp. 165-204.

BECKER Howard, Outsiders: Studies in the Sociology of Deviance, New York, The Free Press, 1963.

BERTRÁN Miriam, «Acercamiento antropológico de la alimentación y salud en México», Phycis, Revista de Saúde Coletiva, vol. 20, n² 2, 2010, pp. 387-411.

BESSIÈRE Jacinthe y TIBÈRE Laurence, « Éditorial : Patrimoines alimentaires », Anthropology of Food, $\mathrm{n}^{\circ}$ 8, 15 de junio, 2010. Disponible en línea: http://aof.revues.org/6782.

BOURDIEU Pierre, La distinción. Criterio y bases sociales del gusto, Madrid, Taurus, 1998.

BOURDIEU Pierre y SAINT MARTIN (de) Monique, «Anatomía del gusto», Actes de la recherche en sciences sociales, $\mathrm{n}^{\circ}$ 5, 1976, pp. 2-81.

BOURGUES Héctor, BENGOA José y O’DONNELL Alejandro (eds.), Historias de la Nutrición en América Latina, México, SLAN, 2009.

BRAUDEL Fernand, Civilización material, economía y capitalismo, siglos XV-XVIII, Alianza Editorial, 2005.

BRUEGEL Martin y LAURIAUX Bruno (dirs.), Histoire et identités alimentaires en Europe, Paris, Hachette, 2002.

CAMOU Ernesto, «La nostalgia del rancho: Notas sobre la cultura urbana y la carne asada» in Shoko DOODE y Emma Paulina PÉREZ (dirs.), Sociedad, economía y cultura alimentaria, Hermosillo, CIAD/CIESAS, 1994, pp. 421-429.

CARDON Philippe, « Regard sociologique sur les pratiques alimentaires des personnes âgées vivant à domicile «, Gérontologie et société, n 134, 2010, pp. 31-42.

CARDON Philippe, « Manger en vieillissant pose-t-il vraiment problème ? Veuvage et transformations de l'alimentation des personnes âgées «, Lien Social et Politiques, n 62, 2009a, pp. 85-95.

CARDON Philippe, « Retraite et alimentation : les effets de la mobilité «, Recherches familiales, $\mathrm{n}^{\circ} 6$, 2009b, pp. 105-115.

CARDON Philippe y GOJARD Séverine, «Les personnes âgées face à la dépendance culinaire : entre délégation et remplacement », Retraite et société, $\mathrm{n}^{\circ}$ 56, 2009, pp. 169-193.

CARRASCO Noelia, «Desarrollos de la antropología de la alimentación en América Latina: hacia el estudio de los problemas alimentarios contemporáneos», Estudios Sociales, vol. 16, n 30, 2007, pp. 79-102.

CASCUDO Luis da Camara, História da alimentação no Brasil, São Paulo, Universidade de São Paulo, 1983. 
CHAVES Mônica, «La restauration hors foyer dans l'État brésilien de Minas Gerais», Journal des Anthropologues, $\mathrm{n}^{\circ}$ 106-107, 2006, pp. 189-204.

COLE Nicki, «Global capitalism organizing knowledge of race, gender and class: The case of socially responsible coffee», Race, Gender and Class, vol. 15, n 1-2, 2008, pp. 170-187.

CONTRERAS Jesús y GRACIA Mabel, Alimentación y Cultura. Perspectivas antropológicas, Barcelona, Ariel, 2005.

CORBEAU Jean-Pierre y POULAIN Jean-Pierre, Penser l'alimentation. Entre imaginaire et rationalité, Paris, Privat, 2002.

CORBEAU Jean-Pierre (coord.), Cuisine, alimentation, métissage, Paris, Bastidiana, 2000.

СОТТОМ Bolfy, «El patrimonio cultural como problema interdisciplinario», Red Patrimonio: Revista digital de estudios en patrimonio cultural, 2007a.

CОтTОМ Bolfy, «Diversidad y enfoques del patrimonio cultural», Cuadernos del Patrimonio Cultural $y$ Turismo, $n^{\circ} 8,2004$.

DONNAT Olivier y TOILA Paul (dirs), Le(s) public(s) de la culture, Paris, Presses de Sciences Po, 2003.

DONNAT Olivier, Les français face à la culture. De l'exclusion à l'éclectisme, Paris, La Découverte, coll. «Textes à l'appui», 1994.

DOUGLAS Mary, «Les structures du culinaire», Communications, vol. 31, 1979, pp. 145-170.

DURKHEIM Émile y MAUSS Marcel, «De quelques formes primitives de classification. Contribution à l'étude des représentations collectives», Année sociologique, nº 6, 1903.

DUVAL Julien, «Distinction studies», Actes de la recherche en sciences sociales, $\mathrm{n}^{\circ} 181-182,2010$, pp. 146-156.

ELOY Florence y PALHETA Ugo, «Cultures juvéniles et enseignement musical au collège», Revue française de pédagogie, $\mathrm{n}^{\circ}$ 163, 1 de junio, 2008. Disponible en línea: http://rfp.revues.org/957.

ELOY Florence, Apprendre à écouter la musique. Culture légitime, culture scolaire et cultures juvéniles, Paris, EHESS, tesis dirigida por Dominique Pasquier, 2012.

ESPEITX Elena, «Los sentidos del patrimonio alimentario en el sur de Europa» in Marcelo ÁLVAREZ y Francisco-Xavier MEDINA (eds.), Identidades en el plato. El patrimonio cultural alimentario entre Europa y América, Barcelona, Icaria, 2008, pp. 45-62.

FERNÁNDEZ ARMESTO Felipe, Historia de la comida: Alimentos, cocina y civilización, Tusquets Editores S.A., 2004.

FISCHLER Claude y MASSON Estelle, Manger. Français, Européens et Américains face à

l'alimentation, Paris, Odile Jacob, 2007.

FLANDRIN Jean-Louis y MONTANARI Massimo, Histoire de l'alimentation, Paris, Fayard, 1996.

FLORES Jesús, Breve historia de la comida mexicana, México, De Bolsillo, 2003.

FLORESCANO Enrique (coord.), El patrimonio cultural de México, México, FCE, 1993.

FREYRE Gilberto, Casa grande e senzala. Formação da familia brasileira sob o regime de economia patriarcal, Rio de Janeiro, Maia e Schmidt, 1933.

GABACCIA Donna, We are what we eat. Ethnic Food and the Making of the Americans, Boston, Harvard University Press, 1998.

GARNSEY Peter, Food and Society in Classical Antiquity, Cambridge, 1999. 
GARCÍA GARZA Domingo, «Una etnografía económica de los tacos callejeros en México. El caso de Monterrey», Estudios Sociales, vol. 19, n³7, 2011, pp. 32-63. Disponible en línea: http:// www.redalyc.org/articulo.oa?id=41716750002.

GARCÍA GARZA Domingo, «Prácticas alimenticias y clasificación social. ¿Los tacos son un alimento 'popular'?», Civitas, vol. 10, n 3, 2010, pp. 430-449. Disponible en línea: http:// revistaseletronicas.pucrs.br/ojs/index.php/civitas/article/viewFile/7464/5970.

GARCÍA GARZA Domingo, L'entreprenariat informel. Le cas des marchands de tacos à Monterrey (Mexique), Paris, EHESS, tesis dirigida por Rémi Lenoir, 2009.

GOJARD Séverine, Le métier de mère, Paris, La Dispute, coll. «Corps santé société», 2010.

GOODY Jack, Cooking, Cuisine and Class, London, Cambridge University Press, 1982.

GRIGNON Claude y GRIGNON Christiane, «Styles d'alimentation et goûts populaires», Revue française de sociologie, 1980, vol. 21, pp. 531-569.

HERPIN Nicolas y VERGER Daniel, Consommation et modes de vie en France. Une approche économique et sociologique sur un demi-siècle, Paris, La Découverte coll. » Grands Repères », 2008.

HIRAI Shinji, Economía política de la nostalgia: un estudio sobre la transformación del paisaje urbano en la migración transnacional entre México y Estados Unidos, México, UAM/Juan Pablos Editor, 2009.

LAMONT Michèle, Money, Morals, and Manners: The Culture of the French and the American UpperMiddle Class, Chicago, University of Chicago Press, 1992.

LÉVI-STRASS Claude, Mythologiques, Paris, Plon, (4 volumes), 1964.

LONG-SOLIS Janet y VARGAS Luis, (eds.), Food Culture in Mexico, Westport/London, Greenwood Press, coll. «Food Culture Around the World», 2005.

MONCUSÍ Albert y SANTAMARINA Beatriz, «Bueno para comer, bueno para patrimonializar. La propuesta de la cocina mexicana como Patrimonio Inmaterial de la Humanidad» in Marcelo ÁLVAREZ y Francisco-Xavier MEDINA (eds.), Identidades en el plato. El patrimonio cultural alimentario entre América y Europa, Barcelona, Icaria, 2008, pp. 127-142.

MAGALHãES (de) Sônia M., A Mesa de Mariana: Produção e consumo de alimentos em Minas Gerais (1750-1850), São Paulo, Annablume/Fapesp, 2004.

MARTÍNEZ Irma y VILLEZCA Pedro, «La alimentación en México. Un estudio a partir de la encuesta nacional de ingresos y gastos de los hogares», Notas: Revista de información y análisis (INEGI), 2003, pp. 26-37.

MINTZ Sidney, Tasting food, Tasting Freedom: Excursions into Eating, Culture, and the Past, Boston, Beacon Press, 1996.

MINTZ Sidney y DUBOIS Christine, «The Anthropology of Food and Eating», Annual Review of Anthropology, $\mathrm{n}^{\circ}$ 31, 2002, pp. 99-119.

ORTIZ Ana Silvia, VÁZQUEZ Verónica y MONTES Margarita, «La alimentación en México. Enfoques y visión de futuro», Estudios Sociales, vol. 13, n² 25, 2005, pp. 8-34.

OSEGUERA David, «La comida. Lugar de encuentro entre disciplinas científicas», Estudios sobre las culturas contemporáneas, vol. 7, n 13, 2001, pp. 141-151.

PETERSON Richard, «Understanding audience segmentation: from elite and mass to omnivore and univore», Poetics, $n^{\circ} 32,1992$, p. 169-194. 
PETERSON Roger y KERN R.M., «Changing highbrow taste: from snob to omnivore», American Sociological Review, vol. 61, n 5, 1996, pp. 900-907.

PILCHER Jeffrey M., Que vivan los tamales! Food and the Making of the Mexican Identity, Albuquerque, University of Mexico Press, 1998.

PILCHER Jeffrey M., Planet Taco: A Global History of Mexican Food, New York, Oxford University Press, 2012.

POULAIN Jean-Pierre (dir.), Dictionnaire des cultures alimentaires, Paris, PUF, 2012.

POULAIN Jean-Pierre, «French gastronomie, french gastronomies» in Dara GOLDSTEIN y Kathrin MERKELE (eds.), Culinary cultures of Europe Identity, Diversity and Dialogue, Estrasburgo, Ediciones del Consejo de Europa, 2005, pp. 157-170.

POULAIN Jean-Pierre, Sociologies de l'alimentation. Les mangeurs et l'espace social alimentaire, Paris, PUF, coll. « Sciences sociales et sociétés «, 2002.

POULAIN Jean-Pierre, Manger aujourd'hui : attitudes normes et pratiques, Toulouse, Privat, 2001.

POULAIN Jean-Pierre, «Les patrimoines gastronomiques et leurs valorisations touristiques» in Rachid AMIROU y Philippe BACHIMON, Le tourisme local, une culture de l'exotisme, L'Harmattan, 2000, pp. 157-183.

POULAIN Jean-Pierre, «Le gout du terroir à l'heure de l'Europe», Ethnologie française, vol. 27, 1997, pp. 18-26.

RITZER George, The MacDonaldization of Society: An Investigation Into the Changing Character of Contemporary Social Life, London, Sage, 1993.

STANZIANI Alessandro, Histoire de la qualité alimentaire XIX ${ }^{e}-X X^{e}$ siècles, Paris, Seuil, coll. « Liber », 2005.

SUREMAIN (de) Charles-Édouard y KATZ Esther, «Modelos alimentarios y recomposiciones sociales en América Latina», Anthrolpology of Food, 20 de diciembre de 2009. Disponible en línea: http://aof.revues.org/6432.

SWIDLER Ann, Talk of Love: How Culture Matters, Chicago, University of Chicago Press, 2001.

TAYLOR Stephen, SMITH Shenna y LYON Phil, «McDonalization and consumer choice in the future: an illusion or the next marketing Revolution?» in Mark ALFINO, John S. CAPUTO y Robert WYNYARD (eds.), Mcdonaldization Revisited. Critical Essays on Consumer Culture, Westport/London, Prager Publishers, 1998, pp. 105-119.

THIESSE Anne-Marie, La création des identités nationales. Europe XVII ${ }^{e}-X^{e}$ siècles, Paris, Seuil, 1999.

TILLY Charles, «Contentious repertoire in Great Britain, 1758-1834», Social Science History, vol. 17, $\mathrm{n}^{\circ} 20$, pp. 253-280.

TINKER Irene, Street Food. Urban Food and Employment in Developing Countries, Oxford, Oxford University Press, 1997.

TORRES Felipe y TRAPAGA Yolanda (eds.), La alimentación de los mexicanos en la alborada del tercer milenio, México, UNAM, 2001.

VARGAS Luis A., «Antropología y alimentación», Antropológicas, n 7, 1993, pp. 22-23.

ZAPATA Sergio, «Patrimonialización de la gastronomía peruana y planteamiento de un proyecto de desarrollo» in Marcelo ÁLVAREZ y Francisco-Xavier MEDINA (eds.), Identidades en el plato. El patrimonio cultural alimentario entre América y Europa, Barcelona, Icaria, 2008, pp. 153-174. 


\section{AUTHORS}

\section{PHILIPPE CARDON}

Maître de conférences en sociologie, Université Lille 3. Chercheur au laboratoire Ceries

(laboratoire de recherche individus-épreuves et société) / Université Lille 3. Chercheur associé au laboratoire ALISS (Alimentation et sciences sociales)/INRA.

Philippe.Cardon@ivry.inra.fr

\section{DOMINGO GARCIA-GARZA}

Maître de conférences en civilisation latino-américaine (Université Charles de Gaulle). Chercheur au CECILLE (Lille 3) et chercheur associé au CESSP (EHESS/Paris 1/CNRS).

domingo.garciagarza@univ-lille3.fr 